\title{
XXXV SPOTKANIE NAUKOWE WYKŁADOWCÓW LITURGIKI W POLSCE
}

XXXV seminarium naukowe wykładowców liturgiki w ośrodkach uniwersyteckich, akademiach, wydziałach teologicznych, wyższych seminariach duchownych odbyło się w gościnnym seminarium duchownym księży Pallotynów w Ożarowie Mazowieckim. Jego temat podyktowała rzymska Instrukcja o niektórych kwestiach dotyczacych wspótpracy wiernych świeckich $w$ ministerialnej postudze kapłana z 15 sierpnia 1997 roku. Tematy referatów koncentrowały się na zagadnieniach posługi świeckich w liturgii. Dołączony został do nich temat diakonatu stałego.

Pierwszy referat wygłosił ks. dr Czesław Krakowiak z Lublina. Mówił o Teologicznych $i$ normatywnych zasadach wspótpracy świeckich $w$ ministerialnej postudze kapłanów. Przypomniał najpierw rozwój tej problematyki w posoborowym okresie życia Kościoła. W 1975 roku Kongregacja Kultu Bożego przygotowała Dyrektorium o posłudze świeckich w liturgii, jednak nigdy nie zostało ono opublikowane. W 1994 roku odbyło się w Rzymie międzynarodowe sympozjum na temat udziału świeckich w ministerialnej posłudze kapłana. Nad tym tematem trwały prace jeszcze kilka lat, a jej owocem była wspomniana wyżej Instrukcja. Nie omawia ona całej problematyki posługiwania świeckich w liturgii, lecz tylko te rodzaje posługi, w których wierni świeccy, w szczególnych wypadkach, mogą zastępować kapłana. W drugiej części swego wystąpienia referent zajął się trudnym zagadnieniem terminologii dotyczącej posługiwania w liturgii. Pojęcia takie jak „ministerium”, „minister”, „munus”, odnoszone są tak do duchownych jak i świeckich. Dlatego konieczne jest dodatkowe rozróżnienie na „ministri ordinati” oraz „ministri non ordinati”. Tylko „ministri ordinati” są określani jako „ministri sacri” i mogą spełniać „sacri ministeri”. Wszyscy razem, duchowni i świeccy, powinni mieć $\mathrm{w}$ sobie ducha służby i wspólnie uczestniczyć $\mathrm{w}$ dziele zbawienia uobecnianym $\mathrm{w}$ liturgii.

W drugim referacie dr Marek Marczewski z Lublina przybliżył uczestnikom problematykę stałego diakonatu. Został on przywrócony przez Sobór Watykański II i od tego czasu trwa refleksja teologiczna nad tą posługą. Specyfika diakonatu wyraża się w pełnieniu funkcji pomocniczych, a nie w przewodniczeniu wspólnocie. Funkcja przewodniczenia jest złączona z biskupem i kapłanem (K. Rahner). Przywrócenie tej posługi w Kościele jest związane z pełniejszym odkryciem diakonijności całego ludu Bożego (I. Congar) i nowym stylem obecności Kościoła w świecie (Kramer). Wyraża się on w pełniejszym naśladowaniu Chrystusa Sługi 
i głębszym rozumieniu powołania do służby. Często spotyka się błędne podejście do problematyki stałego diakonatu wyrażone w zdaniu: „Nie potrzebujemy diakonów, gdyż mamy dość kapłanów". Myślenie to sprowadza funkcję diakona do zastępowania kapłana, gdy go brak. Nie jest to słuszne. Diakonat jest darem Pana ubogacającym Kościół i ma swoje własne, a nie zastępcze tylko miejsce we wspólnocie wierzących (A. Altana). Druga część referatu dotyczyła polskiego kontekstu wprowadzenia stałego diakonatu. Referent ukazał, że właściwie we wszystkich obszarach życia dzisiejszego Kościoła w Polsce posługa diakona może mieć swoje miejsce i wnieść ważny wkład w rozwój wiary. Diakonat jest bowiem powołaniem, danym przez Boga. Przyjmuje się go przez sakrament święceń, a więc diakon nie jest ,świeckim” lecz „duchownym”.

Temat stałego diakonatu powracał nieustannie w dyskusji. Dopytywano o sposób podjęcia tej problematyki przez Polski Synod Plenarny. Ks. bp Stefan Cichy, który uczestniczył w pracach Synodu poinformował, że był przygotowany odpowiedni punkt w projekcie dokumentów synodalnych, lecz w ostatniej wersji został wykreślony. Wprawdzie Synod nie ma władzy wprowadzania stałego diakonatu w Polsce, lecz temat nie został zamieszczony nawet $\mathrm{w}$ formie postulatu. W związku z tym wykładowcy liturgiki postanowili skierować pismo do Konferencji Episkopatu z prośbą o wprowadzenie w Polsce tego urzędu kościelnego. O przygotowanie odpowiedniego pisma został poproszony ks. bp Stefan Cichy.

Pozostałe referaty i komunikaty, a także dyskusja, dotyczyły różnorodnych posług podejmowanych przez wiernych świeckich w liturgii. Ogólne zasady tego posługiwania omówił ks. dr Stanisław Szczepaniec z Krakowa. Odwołał się w swoim referacie do trzeciego rozdziału Ogólnego wprowadzenia do Mszału Rzymskiego, które omawia problematykę posługiwania w Eucharystii. Czynności świeckich są dwojakiego rodzaju: zwyczajne i szczególne. Te pierwsze są podejmowane przez wszystkich i są najważniejsze (słuchanie słowa, składanie ofiary, przystępowanie do Komunii świętej, śpiewy, aklamacje, modlitwy, postawy, gesty), gdyż w nich przede wszystkich dokonuje się ,świadome, czynne i owocne uczestnictwo". Drugi rodzaj czynności ma charakter służebny wobec całego zgromadzenia i jest podejmowany w konkretnej celebracji przez wybranych członków zgromadzenia (akolita, lektor, kantor, ministranci, komentatorzy i inni usługujący). Referent podjął także próbę ukazania głębszego związku między spełnianą w liturgii posługą, a osobistym powołaniem człowieka. Czynność liturgiczna jest znakiem, w którym wyraża się tajemnica działania Bożego, a także tajemnica człowieka (jeśli człowiek objawia się w swoim działaniu, to tym bardziej w „liturgicznej posłudze").

Ks. dr Edmund Skalski z Gdyni omówił zagadnienie Formacji i postugi nadzwyczajnego szafarza Eucharystii przypominając podjęte w tym względzie ustalenia Konferencji Episkopatu Polski i sugerując potrzebę krajowego duszpasterstwa nadzwyczajnych szafarzy Eucharystii. 
Ks. dr Eugeniusz Stencel z Pelplina podjął podobne zagadnienia w odniesieniu do zakrystiana. Przypomniał rozwój tej posługi w historii, ukazał jego zadania dzisiaj i wskazał na potrzebę większej formacji osób pełniących tę posługę.

Kolejny komunikat wygłosił ks. prof. dr hab. Jerzy Kopeć. Mówił o Formacji $i$ postudze ministrantów $i$ ministrantek. Przypomniał krótko historię tej posługi w Kościele, wspomniał o wkładzie w formację tych osób Krajowego Duszpasterstwa Służby Liturgicznej, omówił wypowiedź Kongregacji Kultu Bożego na temat kan. 203, § 2, w której Kongregacja dopuszcza możliwość wprowadzenia w diecezjach i parafiach ministrantek, zostawiając jednak decyzję biskupowi miejsca, który powinien zasięgnąć rady Konferencji Episkopatu. W Polsce w niektórych parafiach zaczynają się pojawiać ministrantki (przykłady podawał m.in. ks. prof. H. Sobeczko w dyskusji).

$\mathrm{Na}$ temat Muzycznych postug $w$ liturgii referat wygłosił ks. prof. dr hab. Zbigniew Wit z Lublina. Rozpoczął od aspektu historycznego omawiając szerzej rolę „schola cantorum” w dziejach muzyki kościelnej, a następnie omówił kolejno zadania, jakie mają do spełnienia w liturgii kantor, psałterzysta, schola, chór oraz organista.

Ostatnim wystąpieniem na sympozjum, a równocześnie wywołującym najdłuższą dyskusję było słowo ks. dra Józefa Górzyńskiego na temat Ministerium lektora $i$ akolity. Autor omówił motu proprio papieża Pawła VI Ministeria quaedam z roku 1972, wprowadzające reformę tzw. „niższych święceń” i dające dostęp do posług lektora i akolity świeckim mężczyznom. Niestety w dalszych latach nastąpiło w tej dziedzinie duże zamieszanie. Niejasność dotyczyła głównie relacji między „ustanowieniem” do posługi lektora, dostępnym tylko dla niektórych, a zwyczajnym spełnianiem funkcji czytania słowa Bożego, które mogą podejmować wszyscy. Niejasność objawia się szczególnie wtedy, gdy pobłogosławieni do posługi lektora młodzi chłopcy wstępowali do seminarium. Niektórzy biskupi błogosławili ich powtórnie do posługi lektora, inni nie. Obecnie wszyscy alumni są ustanawiani do tej posługi $\mathrm{w}$ seminarium, niezależnie od tego, jakie błogosławieństwo przyjęli wcześniej. Rodzi to pytanie, czym było wcześniejsze błogosławieństwo. Dyskusja, po wygłoszeniu tego komunikatu, zmierzała ku temu, aby podjąć jakieś kroki wprowadzające więcej światła na ten obszar życia Kościoła w Polsce. Zdecydowano, że zostanie wysłane odpowiednie pismo do Konferencji Episkopatu, z prośbą o dopuszczenie do posługi (ustanowienia na stałe zgodnie z kan. 203, § 1) lektora świeckich mężczyzn oraz o wyjaśnienie sytuacji alumnów, którzy przed wstąpieniem do seminarium przyjęli taką posługę. Do przygotowania odpowiedniego pisma wybrano autora referatu, ks. dra J. Górzyńskiego oraz ks. dra Stanisława Szczepańca.

Sympozjum podsumował przewodniczący Sekcji Wykładowców Liturgiki ks. prof. dr hab. Adam Durak SDB. Przypomniał główne myśli referatów i podzięko- 
wał wszystkim za czynny udział. Uczestniczyło w nim dwóch biskupów, którzy w kolejnych dniach przewodniczyli Eucharystii i skierowali do zebranych pasterskie słowo. W pierwszym dniu przewodniczył ks. bp prof. dr hab. Wacław Świerzawski, a w drugim dniu ks. bp dr Stefan Cichy.

Kraków

KS. STANISEAW SZCZEPANIEC

\section{ks. Kazimierz Panuś}

\section{SPRAWOZDANIE PREZESA \\ POLSKIEGO TOWARZYSTWA TEOLOGICZNEGO \\ ZA ROK 1998}

\section{STAN TOWARZYSTWA}

Ostatnie Walne Zebranie Polskiego Towarzystwa Teologicznego w Krakowie, jakie odbyło się w dniu 17 lutego 1998 r., obejmowało część sprawozdawczą za rok 1997, wykład ks. dra Józefa Wołczańskiego nt. Geneza, program i pierwsze lata istnienia Polskiego Towarzystwa Teologicznego we Lwowie oraz wręczenie medali Zastużony dla PTT ks. prof. Tadeuszowi Wojciechowskienu i ks. dyr. Rudolfowi Bromowi. Zeszłoroczne walne zebranie otwarło trzeci, ostatni rok kadencji obecnego zarządu Towarzystwa wybranego 14 lutego 1996 r. Ukonstytuowany wtenczas Zarząd Towarzystwa działał w roku sprawozdawczym w następującym składzie:

\section{ZARZĄD}

Prezes:

ks. dr hab. Kazimierz PANUŚ

Wiceprezes:

o. dr Józef MARECKI OFMCap

Sekretarz:

ks. mgr Kazimierz MOSKAŁA

Skarbnik:

ks. lic. Andrzej MOJŻESZKO

Bibliotekarz:

ks. dr Jan BEDNARCZYK

Kierownik Sekcji Wydawniczej: ks. prof. dr hab. Stefan KOPEREK CR

\section{KOMISJA KONTROLUJĄCA}

Przewodniczacy:

ks. dr Kazimierz WALICZEK 